\title{
Dilovası Hava Kalitesinin Ulusal Mevzuata Göre Değerlendirilmesi
}

\author{
Merve Y1lmaz ${ }^{*}$, Hande Emanet Beba ${ }^{2}$, Umur Dinç$^{3}$, Zeynep Feriha Ünal ${ }^{4}$, Hüseyin Toros ${ }^{5}$, Zübeyde Öztürk ${ }^{6}$ \\ 1 İstanbul Teknik Üniversitesi, Uçak ve Uzay Bilimleri Fakültesi, Meteoroloji Mühendisliği Bölümü, İstanbul, Türkiye (ORCID: 0000-0002-1434-6120) \\ 2 İstanbul Teknik Üniversitesi, İnşaat Fakültesi, Ulaştırma Mühendisliği Bölümü, İstanbul, Türkiye (ORCID: 0000-0002-7985-9955) \\ 3 İstanbul Teknik Üniversitesi, Uçak ve Uzay Bilimleri Fakültesi, Meteoroloji Mühendisliği Bölümü, İstanbul, Türkiye (ORCID: 0000-0003-2439-8757) \\ 4 İstanbul Teknik Üniversitesi, Uçak ve Uzay Bilimleri Fakültesi, Meteoroloji Mühendisliği Bölümü, İstanbul, Türkiye (ORCID: 0000-0002-6849-7637) \\ 5 İstanbul Teknik Üniversitesi, Uçak ve Uzay Bilimleri Fakültesi, Meteoroloji Mühendisliği Bölümü, İstanbul, Türkiye (ORCID: 0000-0002-3028-6308) \\ 6 İstanbul Teknik Üniversitesi, İnşaat Fakültesi, Ulaştırma Mühendisliği Bölümü, İstanbul, Türkiye (ORCID: 0000-0002-2962-6459)
}

(İlk Geliş Tarihi 14 Mart 2020 ve Kabul Tarihi 6 Temmuz 2020)

(DOI: $10.31590 /$ ejosat.703579)

ATIF/REFERENCE: Yılmaz, M., Emanet Beba, H., Dinç, U., Ünal, Z. F., toros, H. \& Öztürk, Z. (2020). Xxxx Xxxx Xxxx. Avrupa Bilim ve Teknoloji Dergisi, (19), 703-714.

\section{Öz}

Türkiye'de hava kalitesinin kontrolü Çevre ve Şehircilik Bakanlığı tarafindan, Hava Kalitesi Değerlendirme ve Yönetimi (HKDY) Yönetmeliği ile sağlanmaktadır. 01.01.2014 tarihi itibariyle her yıl kademeli olarak azalan tolerans paylarıyla birlikte o yıla ait limit değerler hesaplanarak 2024 yılına kadar tüm kirleticiler için $\mathrm{AB}$ limitlerine ulaşılması planlanmıştır. Dilovası'nda bulunan dört adet hava kalitesi istasyonunda $\mathrm{SO}_{2}, \mathrm{PM}_{10}, \mathrm{NO}_{2}, \mathrm{NO}_{x}, \mathrm{CO}$ ve $\mathrm{O}_{3}$ konsantrasyonları saatlik olarak ölçülmektedir. 2014-2019 yılları arasında ölçülen kirlilik seviyeleri, Yönetmelik'te her yıl için belirlenmiş limit değerler ile kıyaslanarak Dilovası hava kalitesi için bir değerlendirme yapılmıştır. Kocaeli OSB istasyonunda yapılan ölçümlere göre $\mathrm{NO}_{2}$ kirliliği insan sağlığı için risk oluşturacak seviyelerdedir. Yönetmelik tarafindan 2018 yllında $\mathrm{NO}_{2}$ için geçerli saatlik limit değerin $\left(260 \mu \mathrm{g} / \mathrm{m}^{3}\right)$ bir y1lda maksimum $18 \mathrm{kez}$ aşılmasına izin verilmesine rağmen, yıl boyunca ölçülen saatlik $\mathrm{NO}_{2}$ konsantrasyonları $73 \mathrm{kez}$ limit değerin üstüne çıkmıştır. Kocaeli Dilovası istasyonunda yapılan ölçümler ise bölgede gözlenen $\mathrm{PM}_{10}$ kirliliğinin insan sağlığı açısından önemli bir risk oluşturduğunu göstermektedir. Özellikle 2017 ve 2018 yıllarında ölçülen günlük PM $_{10}$ seviyelerinde ani artışlar yaşandığı görülmüştür. Yönetmelik’te günlük $\mathrm{PM}_{10}$ limitlerinin bir yıl boyunca maksimum 35 defa aşılabileceği söylenmesine ragmen, bu yıllarda limit değerin üstüne çıkılan gün sayısı sırasıyla 91 ve 113'tür. Değerlendirilen diğer iki istasyon Dilovası İMES OSB arazisi içinde yer almaktadır. İMES OSB 1 ve İMES OSB 2 istasyonlarında 2015 yılının sonlarında ölçüm yapılmaya başlandı̆̆ için bu istasyonların değerlendirilmesi son üç yılı (2016-2019) kapsamaktadır. İMES OSB 1 istasyonunda yapılan ölçümlere bakıldığında insan sağlığı açısından en riskli kirleticinin PM $_{10}$ olduğu görülmüştür. 2016, 2017 ve 2018 yıllarında insan sağlığını korumak amacıyla belirlenmiş günlük PM $_{10}$ limitleri bir yıl boyunca 42, 92 ve 73 defa aşılmıştır ( $>35$ gün). IMMES OSB 2 istasyonunda izlenen kirlilik değerleri ise Yönetmelik'e göre herhangi bir tehdit oluşturmayacak seviyelerdedir. Öte yandan Kocaeli OSB, Kocaeli Dilovası ve IMES OSB 1 istasyonlarında ölçülen yıllık ortalama $\mathrm{NO}_{\mathrm{x}}$ konsantrasyonları her yıl ekosistemin korunması amacıyla belirlenmiş yıllık $\mathrm{NO}_{\mathrm{x}}$ limit değerinin $\left(30 \mu \mathrm{g} / \mathrm{m}^{3}\right)$ üzerine çıkmıştır. Kocaeli OSB ve Kocaeli Dilovası'nda ölçülen $\mathrm{SO}_{2}$ kirlilik seviyeleri zaman zaman limit değerlerin ve uyarı eşiğinin üstünde gözlense de $\mathrm{PM}_{10}$ ve $\mathrm{NO}_{x}$ kirlilikleri kadar büyük boyutlarda değildir. Kocaeli Dilovası, İMES OSB 1 ve İMES OSB 2 istasyonlarında ölçülen $\mathrm{CO}$ ve $\mathrm{O}_{3}$ kirlilikleri ise limit değerlerin çok altında gözlendiğinden Dilovası'nda insan sağlığı ve ekosistem için herhangi bir risk oluşturmamaktadır.

Anahtar Kelimeler: Hava Kalitesi, Hava Kirliliği, Dilovası, Hava Kalitesi Değerlendirme ve Yönetimi (HKDY) Yönetmeliği.

\section{Evaluation of Dilovası Air Quality Accordance with National Legislation}

\begin{abstract}
Air quality in Turkey is controlled by Air Quality Assessment and Management (HKDY) Regulation provided by Ministry of Environment and Urban Planning. EU limits are targeted for the air quality limit values determined in the Regulation. By 01.01.2014, it is planned to reach the EU limits for all pollutants in 2024 by calculating the limit values for that year with the gradually decreasing
\end{abstract}

* Sorumlu Yazar: İstanbul Teknik Üniversitesi, Uçak ve Uzay Bilimleri Fakültesi, Meteoroloji Mühendisliği Bölümü, İstanbul, Türkiye, merveeyilmazz89@gmail.com 
tolerance shares every year. $\mathrm{SO}_{2}, \mathrm{PM}_{10}, \mathrm{NO}_{2}, \mathrm{NO}_{\mathrm{x}}, \mathrm{CO}$ and $\mathrm{O}_{3}$ concentrations are measured hourly at four air quality stations in Dilovasi. The pollution levels measured between 2014-2019 are compared with the limit values determined for each year together with the tolerance values. According to the Kocaeli OSB measurements, $\mathrm{NO}_{2}$ pollution levels pose risk for human health. Although, the number of days exceeding the hourly limit value allowed in the Regulation is 18 for a year, the hourly $\mathrm{NO}_{2} \operatorname{limit}\left(260 \mu \mathrm{g} / \mathrm{m}^{3}\right)$ was exceeded 73 times in 2018. According to the measurements at the Kocaeli Dilovas1, $\mathrm{PM}_{10}$ pollution poses risk for human health. Although it is stated in the Regulation that the daily $\mathrm{PM}_{10}$ limits can be exceeded a maximum of 35 times a year, the number of days exceeding the limits are 91 and 113 in 2017 and 2018 respectively. The other two stations are located in Dilovas1 IMES OSB land. Because the measurements started at the end of 2015, the evaluation of these stations covers the last three years (2016-2019). According to the İMES OSB 1 measurements, the most dangerous pollutant in terms of human health is $\mathrm{PM}_{10}$. The daily $\mathrm{PM}_{10}$ limits were exceeded 42,92 and 73 times during 2016, 2017 and 2018 respectively (> 35 days). The pollution levels at IMES OSB 2 are not threatening. On the other hand, $\mathrm{NO}_{\mathrm{x}}$ pollution observed in Kocaeli OSB, Kocaeli Dilovası and IMES OSB 1 stations is dangerous for the ecosystem for all years. The annual average $\mathrm{NO}_{\mathrm{x}}$ concentrations measured at these stations exceeded every year the annual $\mathrm{NO}_{\mathrm{x}}$ limit value $\left(30 \mu \mathrm{g} / \mathrm{m}^{3}\right) \mathrm{determined}$ to protect the ecosystem. Although $\mathrm{SO}_{2}$ pollution levels measured in Kocaeli OSB and Kocaeli Dilovasi are sometimes observed above the limit values and warning threshold, they are not as hazardous as $\mathrm{PM}_{10}$ and $\mathrm{NO}_{\mathrm{x}}$ pollution. Since $\mathrm{CO}$ and $\mathrm{O}_{3}$ pollution measured at Kocaeli Dilovas1, IMES OSB 1 and İMES OSB 2 stations are observed below the limit values, they do not pose any risk for human health and ecosystems in Dilovası.

Keywords: Air Quality, Air Pollution, Dilovas1, Air Quality Assessment and Management Regulation.

\section{Giriş}

Hava kirliliği, atmosferde bulunan gazların, su buharının ve partiküler maddelerin konsantrasyonlarının normal değerlerin üzerinde gözlenmesi olarak tanımlanır ve hava kirleticilerinin başında partiküler maddeler $\left(\mathrm{PM}_{2.5}\right.$ ve $\left.\mathrm{PM}_{10}\right)$, karbon dioksit $(\mathrm{CO})$, karbon monoksit $(\mathrm{CO})$, kükürt dioksit $\left(\mathrm{SO}_{2}\right)$, azot oksitler $\left(\mathrm{NO}_{\mathrm{x}}\right)$ ve uçucu organik bileşikler (VOC) gelmektedir (Vallero, 2014). Artan nüfus ve gelişen teknoloji, kentlerin büyümesine ve sanayi kuruluşlarının yaygınlaşmasına, dolayısıyla hava kirliliğinin artmasına sebep olmaktadır. Isınma amaçlı yakılan fosil yakıtlar, endüstriyel emisyonlar, trafikteki taşıtlardan salınan egzoz gazları, termik santraller ve çimento fabrikaları başlıca hava kirliliği kaynakları olarak kabul edilir (Güler, 1993). Kirletici emisyonlarının yanısıra bir bölgede gözlenen hava kirliliği seviyelerinin rüzgar, sis ve yüksek basınç gibi meteorolojik etmenler ile ilişkili olarak yükseldiğini ortaya koyan çeşitli çalışmalar mevcuttur (Özdemir, 2019; Özdemir ve diğ., 2018; Unal ve diğ., 2011).

Dünya Sağlık Örgütü'ne göre hava kirliliği, özellikle partiküler madde kirliliği, insan ve çevre sağlığını etkileyen temel çevre sorunlarının başında gelmektedir (WHO, 2003). Partiküler maddeler atmosferde standart şartlarda katı ya da sıv1 olarak bulunan, boyutları 0,1-100 $\mu \mathrm{m}$ arasında değişen taneciklerdir. Aeorodinamik çapı 2,5 $\mu$ m’ye kadar olan partiküller $\mathrm{PM}_{2.5}, 10 \mu \mathrm{m}$ 'ye kadar olan partiküller ise $\mathrm{PM}_{10}$ olarak tanımlanmaktadır. Solunum yoluyla vücuda alınan partiküller, solunum rahatsızlıkları ve kardiovasküler rahatsızlıklar sebebiyle hastanelere yapılan başvuruların ve ölümlerin artmasına sebep olmaktadır (Brunekreef ve Holgate, 2002; Çapraz ve diğ., 2017). Katı veya sıvı halde bulunan bu parçacıklar, aynı zamanda dünyanın enerji dengesini, hidrolojik çevrimi ve atmosfer sirkülasyonunu etkileyerek atmosferdeki sera etkisine katkı yapmaktadır (EPA, 2012). Çimento fabrikaları, metal işleyen endüstriyel tesisler, taşıtlar ve evlerde yakılan kömürler partiküler madde kirliliğinin antropojenik sebepleri olarak gösterilebilir (Mazzei ve diğg., 2008). Bunların yanında kuvvetli rüzgarlar ile toz taşınması bazı bölgelerde partiküler madde kirliliğininin yükselmesine sebep olmaktadır. Örneğin, Akdeniz'de oluşan kuvvetli siklonlar zaman zaman Sahra Çölü üzerinden Türkiye'ye çöl tozu taşıyarak ülkemizin batı ve iç bölgelerinde partiküler madde kirliliğini artırmaktadır (Özdemir, 2019). Ülkemizde PM ${ }_{2.5}$ kirliliğini kapsayacak yasal düzenleme henüz yapılmadığından, partiküler madde kirliliği konusunda sadece $\mathrm{PM}_{10}$ parametresi dikkate alınmaktadır (HKDYY, 2008). Bir diğer önemli kirlilik parametresi olan CO, karbon temelli fosil yakıtların tam yanmaması sonucunda atmosfere salınan bir bileşiktir ve kararlı bir yapıya sahip olduğundan atmosferde iki aydan fazla süreyle kalabilmektedir (Tam ve diğ., 2012). Kan hücrelerinin içinde bulunan hemoglobine bağlanarak hücrelerin ihtiyacı olan oksijeni almalarına engel olmakta, bu sebeple ölümlere sebep olabilmektedir (Raub ve diğ., 2000). Yetersiz kalitede kömürlerin kullanıldığı, eski yanma teknolojileri ile işletilen termik santraller ve trafikte bekleyen araçlar CO kirliliğinin başlıca sebeplerindendir (Andre ve diğ., 2009). Atmosferde bulunan $\mathrm{SO}_{2}$ 'nin başlıca kaynakları ise evsel ısınmada, ulaşımda ve endüstriyel tesislerde kükürt içeriği yüksek fosil yakıt kullanımı ve volkanik patlamalardır. Atmosferdeki $\mathrm{SO}_{2}$ varlığı solunum yolu hastalıklarına sebep olmalarının yanı sıra asit yağmurlarına da yol açabilmektedir (Wigenstam ve diğ., 2016;Toros, 2000). Azot monoksit (NO) ve azot dioksit $\left(\mathrm{NO}_{2}\right)$ kirleticileri, konsantrasyonlarının toplanması suretiyle $\mathrm{NO}_{\mathrm{x}}$ parametresi ile temsil edilmekte ve genellikle taşıt emisyonları olarak bilinmektedir (HKDYY, 2008). NO renksiz, kokusuz bir gaz olup yüksek sıcaklık altında yanma işlemi sırasında havadaki azot $\left(\mathrm{N}_{2}\right)$ ve oksijenin $\left(\mathrm{O}_{2}\right)$ tepkimesi sonucunda ortaya çıkar ve yanmanın tüm şekillerinde meydana gelmektedir (Iwamoto ve Hamada, 1991). İnsan kaynaklı $\mathrm{NO}_{2}$ ise gübreleme gibi noktasal kaynaklardan ve taşıtlar gibi çizgisel kaynaklardan atmosfere salınmaktadır. Azot oksitler göz ve solunum yolu hastalıkları ile asit yağmurlarına sebep olmaktadırlar (Chen ve diğ., 2007). Ozon $\left(\mathrm{O}_{3}\right)$ kirliliği ise atmosferde bulunan $\mathrm{NO}_{\mathrm{x}}$ ve VOC sebebiyle başlayan bir dizi fotokimyasal reaksiyon sonucunda meydana gelmektedir. (Ebi ve McGregor, 2008).

Halk ve çevre sağlığını hava kirliliğinin olumsuz etkilerinden korumak için etkin bir hava kalitesi yönetiminin geliştirilmesi ve uygulanması oldukça önemlidir (MARKA, 2012). Bu sebeple ülkemizde sürekli olarak hava kalitesi ölçümleri yapılmakta ve sonuçları kamuoyu ile anlık olarak paylaşılmaktadır (ÇŞB, 2019a). Hava kirliliğinin durumunu kamuoyuna açıklarken halkın kolayca anlayabileceği bir sınıflama sistemi kullanılmaktadır. Tüm dünyada yaygın olarak kullanılan, Hava Kalitesi İndeksi (HKİ) denilen bu sınıflama sistemi ile havadaki kirleticilerin konsantrasyonlarına göre hava kalitesi iyi, orta, kötü, tehlikeli vb. şeklinde derecelendirilmektedir. Dünyanın pek çok ülkesinde indeks hesaplanmasında kullanılan yöntem ve kriterler, kendi ülkelerinde uygulanan hava kalitesi standartlarına uygun şekilde oluşturulmuştur. Ulusal Hava Kalitesi İndeksi (UHKİ), Amerika Birleşik Devletleri Çevre Koruma Ajansı (EPA) Hava Kalitesi İndeksi'nin ulusal mevzuatımız ve sınır değerlerimize uyarlanması sonucu oluşturulmuştur. Tablo 1'de $\mathrm{PM}_{10}, \mathrm{CO}, \mathrm{SO}_{2}, \mathrm{NO}_{2}$ ve $\mathrm{O}_{3}$ için belirlenen UHKI kesme noktaları verilmektedir. 
Tablo 1. UHKİ Kesme Noktaları (ÇŞB, 2019a)

\begin{tabular}{c|c|c|c|c|c|c}
\hline \multirow{2}{*}{ İndeks } & \multirow{2}{*}{$\mathbf{H K I}$} & $\mathbf{S O}_{2}\left[\boldsymbol{\mu g} / \mathbf{m}^{\mathbf{3}}\right]$ & $\mathbf{N O}_{2}\left[\boldsymbol{\mu g} / \mathbf{m}^{\mathbf{3}}\right]$ & $\mathbf{C O}\left[\boldsymbol{\mu g} / \mathbf{m}^{\mathbf{3}}\right]$ & $\mathbf{O}_{3}\left[\boldsymbol{\mu g} / \mathbf{m}^{\mathbf{3}}\right]$ & $\mathbf{P M}_{\mathbf{1 0}}\left[\boldsymbol{\mu g} / \mathbf{m}^{\mathbf{3}}\right]$ \\
\cline { 3 - 7 } & & $\mathbf{1 ~ S a .}$ Ort. & $\mathbf{1 ~ S a .}$ Ort. & $\mathbf{8 ~ S a . ~ O r t . ~}$ & $\mathbf{8 ~ S a . ~ O r t . ~}$ & $\mathbf{2 4}$ Sa. Ort. \\
\hline İyi & $0-50$ & $0-100$ & $0-100$ & $0-5500$ & $0-120$ & $0-50$ \\
\hline Orta & $51-100$ & $101-250$ & $101-200$ & $5501-10000$ & $121-160$ & $51-100$ \\
\hline Hassas & $101-150$ & $251-500$ & $201-500$ & $10001-16000$ & $161-180$ & $101-260$ \\
\hline Sağlıksız & $151-200$ & $501-850$ & $501-1000$ & $16001-24000$ & $181-240$ & $261-400$ \\
\hline Kötü & $201-300$ & $851-1100$ & $1001-2000$ & $24001-32000$ & $241-700$ & $401-520$ \\
\hline Tehlikeli & $301-500$ & $>1101$ & $>2001$ & $>32001$ & $>701$ & $>521$ \\
\hline
\end{tabular}

Anlık olarak ölçülen kirlilik seviyelerinin HKİ sistemi kullanılarak kamuoyuyla paylaşılması halkın ve sorumlu kuruluşların günlük faaliyetlerini planlamaları açısından oldukça önemlidir. Bununla birlikte gelecek faaliyetlerin planlanması ve tehlike anında uygulanması gereken tedbirlerin belirlenmesi için veri madenciliği yöntemleri ile HKİ tahmini son yıllarda üzerinde durulan konulardan biridir (Zheng ve diğ., 2015; Freeman ve diğ., 2018; Li ve diğ., 2019). Ancak hava kalitesi sorunlarının çözümünde en etkili adım bütünleşik bir mevzuat yardımıyla kusursuz işleyecek bir hava kalitesi yönetim sistemi oluşturmaktır (Feng ve Liao, 2016). Hava kirliliğinin insan ve çevre sağlığını olumsuz yönde etkilemeye başlayacağı seviyeleri belirlemek ve tehlikeli seviyelere ulaşılması durumunda uygulanacak yaptırımları ortaya koymak için hükümetler tarafından kanunlar ve yönetmelikler hazırlanmaktadır. Bu doğrultuda Avrupa Birliği $(\mathrm{AB})$ tarafından hava kalitesi direktifleri hazırlanmış ve $\mathrm{AB}$ 'ye üye tüm ülkeler için hedefler belirlenmiştir (Gemmer ve Bo, 2013). 2008 yılında yayımlanan Yeni Hava Kalitesi Direktifí'nde başlıca kirleticiler için tanımlanmış sınır değerler Tablo 2'de verilmiştir.

Tablo 2. Indeksi Hesaplanan Parametrelerin AB Sinır Değerleri (CEC, 2008)

\begin{tabular}{c|c|c|c|c|c}
\hline \multirow{2}{*}{ Parametreler } & $\mathrm{SO}_{2}\left[\boldsymbol{\mu g} / \mathbf{m}^{3}\right]$ & $\mathrm{NO}_{2}\left[\boldsymbol{\mu g} / \mathrm{m}^{3}\right]$ & $\mathrm{CO}\left[\boldsymbol{\mu g} / \mathrm{m}^{3}\right]$ & $\mathrm{O}_{3}\left[\boldsymbol{\mu g} / \mathbf{m}^{3}\right]$ & $\mathbf{P M}_{10}\left[\boldsymbol{\mu g} / \mathbf{m}^{3}\right]$ \\
\cline { 2 - 6 } & $\mathbf{1 ~ S a . ~ O r t . ~}$ & 1 Sa. Ort. & 8 Sa. Ort. & 8 Sa. Ort. & 24 Sa. Ort. \\
\hline Sinır Değerler & 350 & 200 & 10.000 & 120 & 50 \\
\hline
\end{tabular}

Türkiye'de ise hava kalitesinin izlenmesi ve hava kirliğinin ölçümü çalışmaları 1986 yılında yürürlüğe giren Hava Kalitesinin Kontrolü Yönetmeliği ile başlamıştır. Söz konusu yönetmelik uzun yıllar boyunca Sağlık Bakanlığı Hıfzıssıhha Enstitüsü tarafından uygulanmış ve 2005 yılında hava kalitesi izleme yükümlülüğü Çevre ve Şehircilik Bakanlığı'na geçmiştir (Gemici ve diğ., 2017). Günümüzde hava kalitesinin korunması için geçerli olan Hava Kalitesi Değerlendirme ve Yönetimi (HKDY) Yönetmeliği Resmi Gazete'de 06.06.2008 tarih ve 26898 sayı ile yürürlüğe girmiş̧tir. 09.08.1983 tarihli ve 2872 sayılı Çevre Kanununun Ek 6 ncı maddesi ile 01.05.2003 tarihli ve 4856 sayılı Çevre ve Orman Bakanlığının Teşkilat ve Görevleri Hakkında Kanunun 1 inci, 2 nci ve 9 uncu maddelerine dayanılarak ve Avrupa Birliği'nin 96/62/EC, 99/30/EC, 2000/69/EC, 2002/3/EC ve 2004/107/EC sayılı direktiflerine paralel olarak hazırlanmıştır (HKDYY, 2008). Yönetmelik'in amacı, hava kirliliğinin çevre ve insan sağlı̆̆ üzerindeki zararlı etkilerini önlemek veya azaltmak için hava kalitesi hedeflerini tanımlamak ve oluşturmak, tanımlanmış metotları ve kriterleri esas alarak hava kalitesini değerlendirmek, hava kalitesinin iyi olduğu yerlerde mevcut durumu korumak ve diğer durumlarda iyileştirmek, hava kalitesi ile ilgili yeterli bilgi toplamak ve uyarı eşikleri aracılığı ile halkın bilgilendirilmesini sağlamaktır (HKDYY, 2008). Söz konusu yönetmeliğin yürürlüğe girmesiyle 1986 yılında yayımlanan Hava Kalitesinin Korunması Yönetmeliği yürürlükten kaldırılmıştır.

Bu çalışmada Kocaeli ilinin Dilovası ilçesinde gözlenen hava kirliliği seviyeleri HKDYY'ne göre değerlendirilmiştir. Dilovası'nda sanayi bölgelerinin yoğunluğu ve ilçenin oldukça sık kullanılan D100 ve TEM karayolları güzergâhında bulunması ilçede gözlenen hava kirliliği sorunlarını artırmaktadır. Bir bölgede gözlenen hava kirliliği sorunlarını çözmek için atılacak ilk adımın kirlilik seviyelerinin geçerli mevzuata göre değerlendirilmesi olduğu düşünülmektedir.

\section{Materyal ve Metot}

\subsection{Hava Kalitesi Değerlendirme ve Yönetimi (HKDY) Yönetmeliği}

Türkiye, hava kalitesi sınır değerleri için $\mathrm{AB}$ limit değerlerini kendisine hedef olarak almıştır. Ancak ölçüm sistemlerinin ve hava kalitesinin istenen seviyelere ulaşması için belirli bir zaman dilimi geçiş dönemi olarak tanımlanmıştı. Yönetmelik'in yürürlüğe girdiği 06.06.2008 tarihinden 31.12.2013 tarihine kadar uzanan geçiş dönemi için kısa ve uzun vadeli hedefler belirlenmiştir. 01.01.2014 tarihi itibariyle AB sınır değerleri, her yıl kademeli olarak azalan tolerans paylarıyla birlikte yeni limit değerler olarak geçerlilik kazanmıştır. En son 2024 tarihinde $\mathrm{NO}_{2}$ limit değerlerine ulaşacak olan Türkiye, bu tarihten itibaren tüm kirletici paremetreler için $\mathrm{AB}$ mevzuatını uygulayacaktır (HKDYY, 2008).

Ülke genelinde kurulu bulunan istasyonlarda ölçülen $\mathrm{SO}_{2}$ ve $\mathrm{PM}_{10}$ parametrelerin yanı sıra $\mathrm{NO}, \mathrm{NO}_{x}, \mathrm{CO}, \mathrm{O}_{3}, \mathrm{PM}_{2.5}$, kurşun, benzen, arsenik, nikel, kadmiyum, benzo(a)piren parametleri için sınır değerler tanımlanmışıtır. Ayrıca, kirlilik konsantrasyonlarına sebep olan emisyon kaynaklarını saptamaya yardım etmek, emisyon envanterlerinin tutarlılığın kontrol etmek, emisyon azaltım stratejilerinin verimliliğini kontrol etmek amacıyla ozon öncüllerinin de ölçülmesi yükümlülüğ̈̈ Yönetmelik’te tanımlanmıştır. Ozon öncül maddeleri, $\mathrm{NO}_{\mathrm{x}}$ 'leri ve bazı VOC'leri kapsamaktadır. Yönetmelik'e göre temel kirleticiler için belirlenmiş değerlendirme limitleri Tablo 3 'te verilmiştir: 
Tablo 3. HKDY Yönetmeliği'nde Verilen Limit Değerler, Tolerans Payları ve Bir Yılda İzin Verilen Maksimum Aşım Sayıları

\begin{tabular}{|c|c|c|c|c|c|c|c|}
\hline \multirow{2}{*}{ Parametre } & \multirow{2}{*}{ Periyot } & \multirow{2}{*}{$\begin{array}{c}\text { Limit değer/bir yılda izin verilen } \\
\text { maksimum aşım sayısı (\#) }\end{array}$} & \multicolumn{5}{|c|}{ Tolerans payı } \\
\hline & & & 2014 & 2015 & 2016 & 2017 & 2018 \\
\hline \multirow{3}{*}{$\mathrm{SO}_{2}\left(\mu \mathrm{g} / \mathrm{m}^{3}\right)$} & Saatlik $^{l}$ & $350 / 24$ & 150 & 120 & 90 & 60 & 30 \\
\hline & Günlük $^{l}$ & $125 / 3$ & 125 & 100 & 75 & 50 & 25 \\
\hline & $Y_{l l l l k} k^{2}$ & 20 & - & - & - & - & - \\
\hline \multirow{2}{*}{$\mathrm{NO}_{2}\left(\mu \mathrm{g} / \mathrm{m}^{3}\right)$} & Saatlik $^{l}$ & $200 / 18$ & 100 & 90 & 80 & 70 & 60 \\
\hline & $Y_{l} l l ı k^{l}$ & 40 & 20 & 18 & 16 & 14 & 12 \\
\hline$N O_{x}\left(\mu g / m^{3}\right)$ & $Y_{l} l l ı k^{2}$ & 30 & - & - & - & - & - \\
\hline \multirow{2}{*}{$\begin{array}{c}P M_{10} \\
\left(\mu g / m^{3}\right)\end{array}$} & Günlük ${ }^{l}$ & $50 / 35$ & 50 & 40 & 30 & 20 & 10 \\
\hline & $Y_{l l l l k}{ }^{l}$ & 40 & 20 & 16 & 12 & 8 & 4 \\
\hline$C O\left(\mathrm{mg} / \mathrm{m}^{3}\right)$ & Günlük (8 saatlik ortalama) ${ }^{l}$ & 10 & 6 & 4 & 2 & - & - \\
\hline \multirow{2}{*}{$O_{3}\left(\mu g / m^{3}\right)$} & Günlük (8 saatlik ortalama) ${ }^{3}$ & $120 / 25$ & - & - & - & - & - \\
\hline & Beş ylllık AOT40 ortalamast ${ }^{4}$ & 18000 & - & - & - & - & - \\
\hline
\end{tabular}

1 İnsan sağlı̆̆ının korunması için

${ }^{2}$ Ekosistemler ve vejetasyonun korunması için

3 İnsan sağlığının korunmasında 2022 için hedef değer

${ }^{4} 2022$ için Mayıs ayından Temmuz ayına kadar 1 saatlik değerlerden hesaplanacak hedef değer. AOT40 ( ( $\left.\mu \mathrm{g} / \mathrm{m}^{3}\right)$ saat olarak ifade edilir), her gün, Merkez Avrupa Saat Dilimi 8:00 ve 20:00 arasında ölçülen sadece 1 saatlik değerler kullanılarak belirli bir zaman dilimi sonunda, $80 \mu \mathrm{g} / \mathrm{m}^{3}$ ile $80 \mu \mathrm{g} / \mathrm{m}^{3}(=40 \mathrm{ppb}) \mathrm{den}$ daha büyük saatlik konsantrasyonlar arasındaki farkın toplamı demektir.

$\mathrm{NO}_{\mathrm{x}}$ için tanımlı limit konsantrasyon değeri, milyar başına parça (ppb) cinsinden $\mathrm{NO}$ ve $\mathrm{NO}_{2}$ konsantrasyonlarının metre küp başına mikrogram $\mathrm{NO}_{2}$ olarak ifade edilen toplamıdır. $\mathrm{CO}$ ve $\mathrm{O}_{3}$ parametreleri için belirlenmiş olan limit değerler maksimum günlük sekiz saatlik ortalamaların hesaplanmasını gerektirmektedir. Maksimum günlük sekiz saatlik ortalama konsantrasyon, saatlik verilerden hesaplanıp her saat güncellenen sekiz saatlik dinamik ortalamalar incelenerek seçilir. Böyle hesaplanan her sekiz saatlik ortalama, sona erdiği güne ait olur, diğer bir ifade ile herhangi bir gün için ilk hesaplama süresi önceki günün 17:00`dan o günün 01:00`a kadarki süredir. Herhangi bir gün için son hesaplama süresi ise o günün saat 16.00`dan 24:00`a kadar olan süredir.

HKDY Yönetmeliği'nin 10. maddesinde, limit değerlerin aşılması durumunda il çevre ve orman müdürlüklerinin ilgili kurum ve kuruluşlarla koordinasyon içerisinde söz konusu limit değerlere ulaşılmasını sağlamak için gerekli önlemleri ortaya koyan bir temiz hava planı hazırlaması veya hazırlatması gerektiği söylenmiştir. Temiz hava planları hazırlanırken halkın katılımının da sağlanması ve bu planın kamuoyuna sunulması gerekmektedir. Dış ortam hava kalitesinin iyileştirilmesi için temiz hava planına dâhil edilecek bilgiler Yönetmelik'in IV numaralı ekinde belirtilmiştir. (HKDYY, 2008).

Yönetmelik tarafından insan sağlığı ve ekosistemin korunması amaçlarına yönelik limit değerler belirlenmesinin yanı sıra hava kalitesi izleme istasyonu kurulum koşulları da belirlenmiştir. İnsan sağlı̆̆ıı korumaya yönelik olarak kurulacak istasyonların öncelikle alansal olarak kentsel ve kent çevresini, kentsel alanda kurulacak istasyonların hava kirlilik kaynaklarından isınma, ulaşım ve sanayi kaynağını, kent çevresinde kurulacak istasyonların ise ağırlıklı olarak sanayi kaynağını temsil etmesi gerekmektedir. Dilovası'nda yer alan dört istasyon kirletici kaynaklarına göre sanayi sınıfina ait istasyonlardır.

Bir ilde yapılacak hava kalitesi izleme faaliyetinin sürekli veya kısa dönemli olup olmayacağına ve kaynak envanteri ve modelleme çalışmalarının yapılıp yapılmayacağına karar verirken Tablo 4 'te verilen eşik değerler kullanılır.

Tablo 4. Değerlendirme ve Uyarı Eşikleri (HKDYY, 2008)

\begin{tabular}{c|c|c|c|c}
\hline Parametre & Periyot & Üst değerlendirme eşiği & Alt değerlendirme eşiği & Uyarı eşiği \\
\hline \multirow{3}{*}{$\mathrm{SO}_{2}\left(\mu \mathrm{g} / \mathrm{m}^{3}\right)$} & Saatlik & - & - & 500 \\
\cline { 2 - 5 } & Günlük & 75 & 50 & - \\
\cline { 2 - 5 } & Ylllı (Ekosistem) & 12 & 8 & - \\
\hline \multirow{2}{*}{$\mathrm{NO}_{2}\left(\mu \mathrm{g} / \mathrm{m}^{3}\right)$} & Saatlik & 140 & 100 & 400 \\
\cline { 2 - 5 } & Ylllık & 32 & 26 & - \\
\hline $\mathrm{NO}_{x}\left(\mu \mathrm{g} / \mathrm{m}^{3}\right)$ & Ylllık (Ekosistem) & 24 & 20 & - \\
\hline \multirow{2}{*}{$P M_{10}\left(\mu \mathrm{g} / \mathrm{m}^{3}\right)$} & Günlük & 30 & 10 & - \\
\cline { 2 - 5 } & Ylllık & 14 & 5 & - \\
\hline $\mathrm{CO}\left(\mathrm{mg} / \mathrm{m}^{3}\right)$ & Günlük (8 saatlik ortalama) & 7 & & \\
\hline
\end{tabular}

Hava kalitesi istasyonlarında saatlik olarak ölçülen konsantrasyon değerlerinin Tablo 4'te verilen periyotlara göre hesaplanan ortalamaları eşik değerler ile kıyaslanır. Uyarı eşiği, ilgili yetkili merci tarafından acil önlemlerin alınacağı seviyedir ve bu seviyenin aşılması halinde nüfusun geneli için kısa süreli maruz kalmadan dolayı insan sağlığına bir risk söz konusudur. Her bir kirletici parametre için üst değerlendirme eşiği ve uyarı eşiğinin aşılması durumunda, bu kirleticiler sürekli olarak sabit istasyonlarda ölçülmeli; ölçümler, 
istasyonun temsil alanından toplanan kaynak envanteri ve hava kalitesi modelleme sonuçları ile desteklenmelidir. Kirletici konsantrasyonları üst ve alt eşik değerler arasında kaldığında, o kirleticilerin sabit ölçümlerle ölçülmesi ve ölçümlerin hava kalitesi modelleme sonuçları ile desteklenmesi gerekir. Konsantrasyonlar eşik değerin altında ise; sadece kaynak envanteri ve hava kalitesi modelleme sonuçları kullanılır.

Yönetmelik'in 11. maddesine göre uyarı eşiği ve limit değerlerin aşılması riski söz konusuysa il çevre ve orman müdürlükleri tarafından bu aşımların süresini kısıtlamak ve riski azaltmak için kısa vadede alınacak önlemleri içeren bir eylem planı hazırlanması gerekmektedir. Eylem planları temiz hava planlarının bir parçası olabilir. Yönetmelik'e göre bu planlar, özel duruma bağlı olarak, limit değerlerin aşılmasına katkıda bulunan motorlu araç trafiğini de içeren faaliyetleri kontrol etmek ve gerektiğinde askıya almak için gerekli önlemleri içerebilir. Uyarı eşiklerinin aşılması insan sağlı̆̆ için risk oluşturduğundan uyarı eşiklerinin aşılması durumunda kamuoyunun bilgilendirilmesi gerekliliği ve kamuoyu ile paylaşılacak asgari bilgiler Yönetmelik’te bildirilmiştir.

\section{2. Çalışma Alanı}

Kocaeli iline bağlı bir ilçe olan Dilovası; kuzeyde ve batıda Gebze ilçesi, doğuda Körfez ilçesi, güneyde İzmit körfezi ile çevrilidir. Gebze'ye 8 km, İzmit'e 25 km ve İstanbul'a $45 \mathrm{~km}$ uzaklıktadır. Üç tepenin arasındaki bir ovada yer alan Dilovası, adını bu ovadan almaktadır. Günümüzde Anadolu'yu İstanbul'a ve Avrupa'ya bağlayan deniz, kara ve demiryolu ağları üzerinde önemli bir konuma sahiptir. Dilovası üzerinden geçen otoyol (E-80) ve devlet karayolu (D-100) trafiğini rahatlatmak için Gebze - İzmir Otoyolu Projesi dahilinde İzmit Körfezi üzerinde inşa edilen Osmangazi Köprüsü Dilovası-Hersek Burnu arasında yer almaktadır. Kuru ve sıvı yük tahmil ve tahliyesine uygun yüksek kapasiteli önemli limanların bulunduğu ilçe aynı zamanda Sabiha Gökçen Havalimanı'na 30 km mesafededir (Öztürk ve diğ. 2019). Ulaşım imkanlarının, ticaret merkezleri ile her yönden bağlantı kurmaya elverişli olması Dilovası ilçesinde sanayileşmenin hızla gelişmesine sebep olmuştur (Dilovası Belediyesi, 2019). Dilovası nüfusu da yıllara göre artış eğilimi göstermektedir. 2019 yılında toplam nüfus 50.551'i bulmuştur. (TÜIK, 2020). İ̧̧ imkanları dolayısıyla endüstriyel tesislerin çevresindeki yerleşim bölgeleri çoğalmakta, bu durum hava kirliliğinin insan sağlığı ve çevre üzerindeki olumsuz etkisini de artırmaktadır. Enerji temini amacıyla fosil yakıtların yakılması, proses atığı veya yan ürünü olarak çıkan gazların bacalardan salınması ve açık depolama alanlarından çevre havasına partiküllerin yayılması Dilovası'ndaki sanayi bölgelerinden kaynaklanan hava kirliliğinin sebeplerindendir (MARKA, 2012). Hava kirliliği incelemelerinde topografik ve meteorolojik koşulların göz önünde bulundurulması kirlilik maruziyeti ve kirliliğin dağılımı açısından oldukça önemlidir. Yerleşimin yoğun olduğu Dilovası ilçe merkezi, çevresine göre daha alçak bir konumda bulunmaktadır. Bu durum bölge havasının rüzgarla yeterince karışamamasına ve zaman zaman bölge üzerinde yüksek atmosferik basınç oluşmasına sebep olmaktadır. Bölge üzerinde çöken hava, kirliliğinin dağılamamasına ve bölgede yaşayan insanların hava kirleticilerine maruz kalma sürelerinin artmasına sebep olabilmektedir (Yılmaz ve diğ., 2019).

Dilovası ilçesinde yer alan Organize Sanayi Bölgeleri (OSB) yaklaşık 2200 hektarlık sanayi alanını kapsamaktadır (Dilovası Belediyesi, DOSB ve İMES OSB, 2019). Dilovası'nda faaliyet gösteren OSB'ler; Dilovası OSB, IV Makina OSB, V GEBKIM (Kimyacılar) OSB, VI. Makine İhtisas (IMES) OSB, Kömürcüler OSB, Mermerciler Sanayi Sitesi’dir. Bölgedeki konut yerleşimleri Dilovası OSB ile bölgeden geçen D-100 ve E-80 karayollarının iki yanında yer almaktadır. 2002 yılında kurulan Dilovası OSB karma nitelikli olup, bölgede ağılıklı olarak metal ve kimya sektöründe sanayi kuruluşları yer almaktadır Dilovası OSB'den sonra kurulan sanayi bölgeleri yerleşimden biraz daha uzağa, yerleşim bölgelerinin kuzey ve kuzeydoğusundaki yüksek arazilere inşa edilmiştir. VI IMES OSB, Dilovası ilçe merkezinin kuzeydoğusunda yaklaşık $300 \mathrm{~m}$. yükseklikte bir arazide yer almaktadır. Dilovası İMES OSB'de yer alan tesisler makine, makine yan sanayi, demir-çelik, otomotiv yan sanayi, plastik enjeksiyon, 1sıl işlem, cam sanayi vb. alanlarda faaliyet göstermektedir (IMES OSB, 2019). Şekil 1'de Dilovası ilçesinde yer alan OSB'ler ve hava kalitesi izleme istasyonlarının konumları gösterilmiştir.
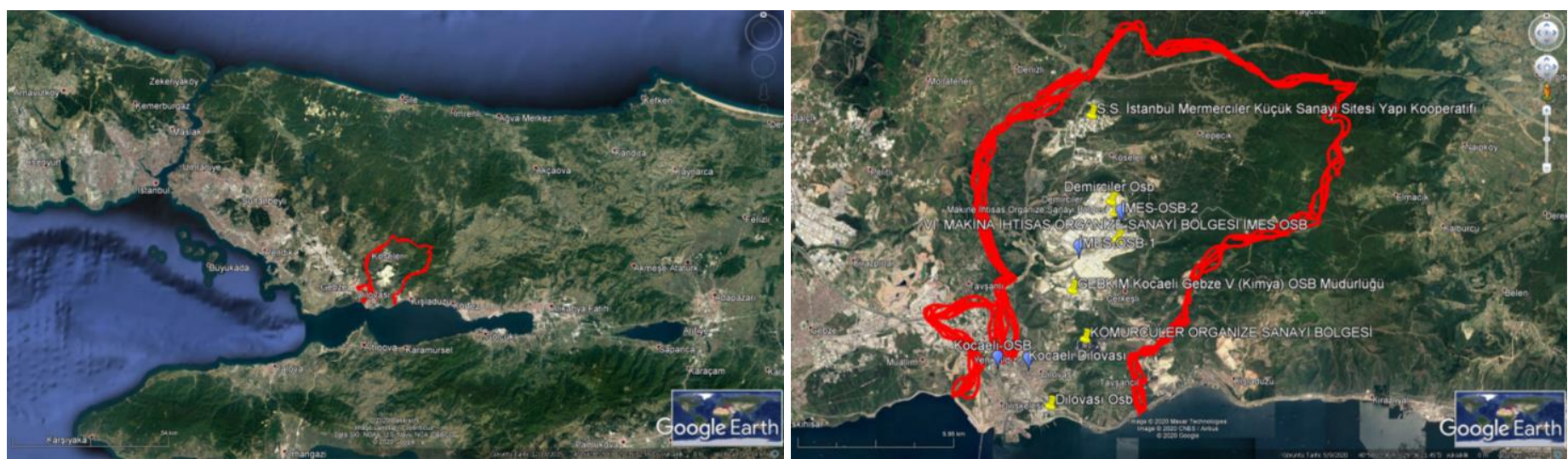

Şekil 1. Dilovası İlçesi, Dilovası'nda Faaliyet Gösteren OSB 'ler ve Hava Kalitesi İzleme İstasyonlarının Konumları 


\subsection{Hava Kalitesinin Ölçümü}

Bölgenin hava kalitesinin sağlanması ve korunması özellikle Dilovası'nda yaşayan ve burada bulunan tesislerde çalışan insanlar için son derece önemlidir. Bu sebeple ilçede bir tanesi T.C. Çevre ve Şehircilik Bakanlığ 1 (ÇŞB)'na, bir tanesi Dilovası Organize Sanayi Bölgesi (DOSB)'ne ve iki tanesi Marmara Temiz Hava Merkezi (MHTM)'ne ait toplam dört adet hava kalitesi izleme istasyonu yer almakta ve sürekli olarak ölçüm yapmaktadır (ÇŞB, 2019b). Şekil 1'de konumları gösterilen bu dört istasyonda ölçülen kirletici parametreler Tablo 5'te verilmiştir. Tüm istasyonlarda kirletici konsantrasyonları saatlik olarak ölçülmekte ve sonuçlar kaydedilmektedir. Ulusal Hava Kalitesi İzleme A ̆̆ı'na ait web sitesinden geçmiş yıllara ait ölçüm sonuçlarına ulaşılabilmektedir. Her bir istasyon verisi, istasyon konumu göz önünde bulundurularak ayrı ayrı incelenmiştir. Yerleşim bölgelerine daha yakın konumda bulunan Kocaeli OSB ve Kocaeli Dilovası istasyonlarında 2014-2019 yılları arasında yapılan beş yıllık ölçüm sonuçları kullanılmıştır. HKDYY'ne göre 01.01.2014 tarihi itibariye kirliliğin değerlendirilmesi için uzun ve kısa vadeli hedeflerin tanımlandığı geçiş dönemi sona ermiş ve kirlilik seviyeleri için AB sınır değerleri yeni hedef olarak belirlenmiştir. Bu sebeple 2014 yılından bu yana ölçülen kirlilik seviyelerinin değerlendirilmesinin uygun olacağı düşünülmüştür. Ancak İMES OSB 1 ve İMES OSB 2 istasyonlarında 2015 Aralık ayından itibaren ölçüm yapılmaya başlandığı için 2016-2019 yılları arasındaki üç yıllık ölçüm sonuçları değerlendirmeye alınmıştır.

Tablo 5. Dilovası'nda Yer Alan Hava Kalitesi İzleme İstasyonlarına Ait Bilgiler

\begin{tabular}{c|c|c}
\hline İstasyon Adı & İstasyon Sahibi & Ölçülen Kirletici Parametreler \\
\hline Kocaeli OSB & ÇŞB & $\mathrm{PM}_{10}, \mathrm{NO} \mathrm{NO}_{2}, \mathrm{NO}_{\mathrm{x}}, \mathrm{SO}_{2}$ \\
\hline Kocaeli Dilovasl & DOSB & $\mathrm{PM}_{10}, \mathrm{NO}, \mathrm{NO}_{2}, \mathrm{NO}_{\mathrm{x}}, \mathrm{SO}_{2}, \mathrm{O}_{3}, \mathrm{CO}$ \\
\hline Kocaeli Dilovası IMES OSB 1 & MTHM & $\mathrm{PM}_{10}, \mathrm{NO} \mathrm{NO}_{2}, \mathrm{NO}_{\mathrm{x}}, \mathrm{CO}$ \\
\hline Kocaeli Dilovast IMES OSB 2 & MTHM & $\mathrm{PM}_{10}, \mathrm{NO}, \mathrm{NO}_{2}, \mathrm{NO}_{\mathrm{x}}, \mathrm{CO}$ \\
\hline
\end{tabular}

Analizlerin öncesinde veri temizleme işlemi uygulanmış, eksik ve gürültülü veri analizlere dahil edilmemiştir. Veri kalite analizi için öncelikle aykırı konsantrasyon değerleri gözden geçirilmiş ve bu değerlerden birkaç saat önceki ve sonraki konsantrasyon değerleri göz önünde bulundurularak anlam ilişkisi bulunamayan aykırı değerler veri setinden çıkarılmıştır. Her bir kirletici için ayrı ayrı veri kalite analizi yapılmıştır. Analiz sonucunda elde edilen değerler her yıl için Yönetmelik’te tolerans paylarıyla birlikte verilen limit değerlerle kıyaslanmıştır. Yönetmelik’e göre, sürekli sabit ölçüm sonuçlarının değerlendirilmesinde veri kalitesinin sağlanabilmesi için veri alımının minimum \%90 olması gerekmektedir.

\section{Araştırma Sonuçları ve Tartışma}

\subsection{Kocaeli OSB istasyonu}

T.C. Çevre ve Şehircilik Bakanlığı'na ait Kocaeli OSB Hava Kalitesi İzleme İstasyonu D-100 ve E-80 karayollarının arasında Dilovası Organize Sanayi Bölgesi'nin (DOSB) içinde yer almaktadır. İstasyonda ölçülen kirletici parametreler $\mathrm{PM}_{10}, \mathrm{SO}_{2}, \mathrm{NO}, \mathrm{NO}_{2}$ ve $\mathrm{NO}_{\mathrm{x}}$ 'dir. Bu istasyonda 2007 yılının Mayıs ayından bu yana kirlilik ölçümü yapılmaktadır ancak bu çalışmada 01.01.2014 ve 01.01.2019 tarihleri arasındaki beş yıllık ölçüm sonuçları değerlendirilmiştir. Bu istasyonda ölçülen $\mathrm{PM}_{10}$ konsantrasyonlarının yıllık ortalama değerleri, Yönetmelik’te insan sağlığının korunması için belirlenmiş yıllık ortalama limit değerlerinin altında kalmıştır. İnsan sağlığının korunması amacıyla $\mathrm{PM}_{10}$ kirliliği için belirlenmiş bir diğer kısıt, günlük (24 saatlik) ortalama değerlerin günlük limit değerleri aştığı gün sayısıdır. Her yıl için tolerans payları sebebiyle limit değerler değişse de bir yılda limit değerin aşılmasına izin verilen maksimum gün sayısı 35’tir. Beş yıl boyunca günlük aşım sayıları limit değer için izin verilen aşım sayısının altında kalmıştır (Tablo 6).

Tablo 6. Kocaeli-OSB İstasyonunda Ölçülen PM10 Konsantrasyonlarının Limit Değerlerle Kıyaslanması

\begin{tabular}{|c|c|c|c|c|c|}
\hline $\mathbf{P M}_{10}\left(\mu \mathrm{g} / \mathrm{m}^{3}\right)$ & 2014 & 2015 & 2016 & 2017 & 2018 \\
\hline Günlük ölçüm sayısı-ölçüm yüzdesi & $253-\% 69$ & $256-\% 70$ & $349-\% 95$ & $353-\% 97$ & $315-\% 86$ \\
\hline Günlük en yüksek değger & 173 & 93 & 138 & 100 & 51 \\
\hline Günlük limit de ğer* & 100 & 90 & 80 & 70 & 60 \\
\hline Günlük limit değer için izin verilen aşım sayısı & 35 & 35 & 35 & 35 & 35 \\
\hline Günlük aşım sayısı & 24 & 1 & 5 & 6 & 0 \\
\hline Ylllık limit değger* & 60 & 56 & 52 & 48 & 44 \\
\hline Yillık ortalama de ğer & 52 & 32 & 32 & 27 & 17 \\
\hline Standart sapma & 53 & 24 & 31 & 25 & 14 \\
\hline
\end{tabular}

* İnsan sağlığının korunması için, yıllık tolerans paylarıyla birlikte hesaplanmış limit değerler.

Tablo 7'de Kocaeli OSB istasyonununda ölçülen $\mathrm{SO}_{2}$ kirliliğinin değerlendirilmesi verilmiştir. Y1llık ortalama değerlere bakıldığında diğer yıllara kıyasla 2018'de $\mathrm{SO}_{2}$ kirlilik ortalamasının hayli azaldığını söylemek mümkündür. HKDY Yönetmeliği’nde insan sağlığının korunması amacıyla $\mathrm{SO}_{2}$ kirleticisi için saatlik ve günlük limit değerler ve bu limit değerlerin bir yıl içinde aşılmasına izin verilen maksimum saat ve gün sayısı belirlenmiştir. Ayrıca ekosistemin korunması için yıllık limit değer tanımlanmıştır. Hesaplanan yıllık ortalamanın ve uyarı eşiği aşım sayısının nispeten yüksek olduğu 2016 ve 2017 yıllarında bile saatlik ve günlük limit değerlerin aşım sayısı izin verilen aşım sayılarının altında kalmıştır. 2016 yılında yıllık ortalama değerin limit değeri aştığı, 2016 dışında her yıl uyarı eşiğinin aşıldığı gözlenmiştir. 
Tablo 7. Kocaeli OSB İstasyonunda Ölçülen $\mathrm{SO}_{2}$ Konsantrasyonlarının Limit Değerlerle Klyaslanması

\begin{tabular}{|c|c|c|c|c|c|}
\hline $\mathrm{SO}_{2}\left(\mu \mathrm{g} / \mathrm{m}^{3}\right)$ & 2014 & 2015 & 2016 & 2017 & 2018 \\
\hline Saatlik ölçüm sayısl-ölçüm yüzdesi & $5690-\% 65$ & $6982-\% 80$ & $8248-\% 94$ & $8476-\% 97$ & $7202-\% 82$ \\
\hline Saatlik en yüksek dĕger & 612 & 549 & 439 & 871 & 410 \\
\hline Saatlik limit dĕger* & 500 & 470 & 440 & 410 & 380 \\
\hline Saatlik limit değer için izin verilen aşım sayısı & 24 & 24 & 24 & 24 & 24 \\
\hline Saatlik aşım sayısı & 2 & 1 & 0 & 14 & 1 \\
\hline Uyarl eşiği & 500 & 500 & 500 & 500 & 500 \\
\hline Uyarl eşiği aşım sayısı & 2 & 1 & 0 & 10 & 1 \\
\hline Günlük ölçüm sayısı-ölçüm yüzdesi & $246-\% 67$ & $294-\% 81$ & $349-\% 95$ & $356-\% 98$ & $315-\% 86$ \\
\hline Günlük en yüksek değer & 103 & 130 & 114 & 177 & 76 \\
\hline Günlük limit değger* & 250 & 225 & 200 & 175 & 150 \\
\hline Günlük limit değer için izin verilen aşım sayısı & 3 & 3 & 3 & 3 & 3 \\
\hline Günlük aşım sayısı & 0 & 0 & 0 & 1 & 0 \\
\hline Ylllık limit değer** & 20 & 20 & 20 & 20 & 20 \\
\hline Yıllık ortalama dĕ̆er & 13 & 18 & 25 & 19 & 7 \\
\hline Standart sapma & 25 & 21 & 25 & 31 & 16 \\
\hline
\end{tabular}

Hava kalitesi izleme istasyonlarında ölçülen $\mathrm{NO}_{\mathrm{x}}$ konsantrasyonları, $\mathrm{NO}_{2}$ ve $\mathrm{NO}$ konsantrasyonlarının toplamını ifade etmektedir. Yönetmelik’te hem $\mathrm{NO}_{\mathrm{x}}$ hem de $\mathrm{NO}_{2}$ için limit değerler belirlendiği için tüm azot oksit parametreleri ayrı ayrı incelenmiştir. Yönetmelik'te $\mathrm{NO}_{\mathrm{x}}$ kirliliğine yönelik ekosistemlerin ve vejetasyonun korunması amacıyla sürekli olarak ölçülen değerlerin yıllık ortalaması için $20 \mu \mathrm{g} / \mathrm{m}^{3}$ seviyesinde bir limit değer belirlenmiş̧ir. Kocaeli OSB istasyonunda ölçülen yıllık ortalama $\mathrm{NO}_{\mathrm{x}}$ konsantrasyonları beş yıl boyunca bu limit değerin oldukça üstündedir. Tablo 8'de görüldüğü üzere 2014, 2015 ve 2016 yıllarında yıllık ortalama $\mathrm{NO}_{\mathrm{x}}$ konsantrasyonları limit değerin yaklaşık olarak üç katı seviyelerindeyken, 2017 ve 2018 yıllarında beş katı seviyelerine çıkmıştır.

Tablo 8. Kocaeli OSB İstasyonunda Ölçülen NOx Konsantrasyonlarının Limit Değerlerle Kıyaslanması

\begin{tabular}{|c|c|c|c|c|c|}
\hline $\mathrm{NO}_{\mathrm{x}}\left(\mu \mathrm{g} / \mathrm{m}^{3}\right)$ & 2014 & 2015 & 2016 & 2017 & 2018 \\
\hline Saatlik ölçüm sayısı-ölçüm yüzdesi & $3369-\% 38$ & $6140-\% 70$ & $7869-\% 90$ & $7667-\% 88$ & $7208-\% 82$ \\
\hline Ylllık ortalama değer & 60 & 67 & 52 & 106 & 118 \\
\hline Standart sapma & 40 & 41 & 64 & 90 & 91 \\
\hline Ylllık limit değger* & 30 & 30 & 30 & 30 & 30 \\
\hline
\end{tabular}

* Ekosistemin korunması için, yıllık tolerans paylarıyla birlikte hesaplanmış limit değerler.

Tablo 9'da verilen $\mathrm{NO}_{2}$ değerlendirmesine göre yıllık ortalama $\mathrm{NO}_{2}$ değerleri 2017 ve 2018 yıllarında insan sağlığının korunması için belirlenmiş yıllık limit değerlerin üstünde gözlenmiştir. Her iki yılda de saatlik limit değer için izin verilen maksimum aşım sayılarının üstünde aşım sayısı kaydedilmiş, özellikle 2018 yılında izin verilen aşım sayısının üç katına çıkıldığı gözlenmiştir. Ayrıca 2018 yılında üç kez uyarı eşiğinin üstüne çıkılmıştır. $\mathrm{Bu}$ durum $\mathrm{NO}_{2}$ kirliliğinin bölgedeki insanların sağlığının korunması için risk oluşturduğunu ortaya koymaktadır.

Tablo 9. Kocaeli OSB İstasyonunda Ölçülen $\mathrm{NO}_{2}$ Konsantrasyonlarının Limit Değerlerle Kıyaslanması

\begin{tabular}{|c|c|c|c|c|c|}
\hline $\mathrm{NO}_{2}\left(\mu \mathrm{g} / \mathrm{m}^{3}\right)$ & 2014 & 2015 & 2016 & 2017 & 2018 \\
\hline Saatlik ölçüm sayısı-ölçüm yüzdesi & $3369-\% 38$ & $6048-\% 69$ & $7869-\% 90$ & $7666-\% 88$ & $7208-\% 82$ \\
\hline Saatlik en yüksek dĕger & 86 & 222 & 231 & 370 & 468 \\
\hline Saatlik limit de ğer* & 300 & 290 & 280 & 270 & 260 \\
\hline Saatlik limit değer içi izin verilen aşım sayısı & 18 & 18 & 18 & 18 & 18 \\
\hline Saatlik aşım sayısı & 0 & 0 & 0 & 19 & 73 \\
\hline Uyarı eşiği & 400 & 400 & 400 & 400 & 400 \\
\hline Uyarl eşiği aşım saylsı & 0 & 0 & 0 & 0 & 3 \\
\hline Ylllık limit dĕger* & 60 & 58 & 56 & 54 & 52 \\
\hline Yıllık ortalama değer & 23 & 27 & 31 & 78 & 79 \\
\hline Standart sapma & 9 & 18 & 31 & 49 & 56 \\
\hline
\end{tabular}




\subsection{Kocaeli Dilovası istasyonu}

Kocaeli Dilovası istasyonu bölgedeki diğer hava kalitesi istasyonlarından farklı olarak herhangi bir OSB içinde değil; yerleşim alanı içinde, Dilovası Mehmet Zeki Obdan İlkokulu bahçesinde yer almaktadır. Doğrudan Dilovası'nda yaşayan insanların soluduğu hava kalitesini izlemektedir. Mart 2007'de kurulan istasyonda $\mathrm{PM}_{10}, \mathrm{SO}_{2}, \mathrm{NO}, \mathrm{NO}_{2}, \mathrm{NO}_{\mathrm{x}}$, $\mathrm{CO}$ ve $\mathrm{O}_{3}$ parametrelerinin saatlik konsantrasyon ölçümleri yapılmaktadır. Bu çalışmada 01.01.2014 ve 01.01.2019 tarihleri arasındaki beş yıllık süre boyunca yapılan ölçüm sonuçları değerlendirilmiştir. Kocaeli Dilovası istasyonunda ölçümü yapılan $\mathrm{PM}_{10}$ konsantrasyonlarına ait veri analizi özeti ve limit değerlerle kıyaslanması Tablo 10’da verilmiştir.

Tablo 10. Kocaeli Dilovası İstasyonunda Ölçülen PM 10 Konsantrasyonlarının Limit Değgerlerle Kıyaslanması

\begin{tabular}{|c|c|c|c|c|c|}
\hline $\mathrm{PM}_{10}\left(\mu \mathrm{g} / \mathrm{m}^{3}\right)$ & 2014 & 2015 & 2016 & 2017 & 2018 \\
\hline Günlük ölçüm sayısl-ölçüm yüzdesi & $324-\% 89$ & $334-\% 92$ & $363-\% 99$ & $338-\% 93$ & $363-\% 99$ \\
\hline Günlük en yüksek değer & 541 & 606 & 385 & 214 & 163 \\
\hline Günlük limit dĕger* & 100 & 90 & 80 & 70 & 60 \\
\hline Günlük limit değer için izin verilen aşım sayısı & 35 & 35 & 35 & 35 & 35 \\
\hline Günlük aşım sayısı & 80 & 80 & 73 & 91 & 113 \\
\hline Ylllık limit değer* & 60 & 56 & 52 & 48 & 44 \\
\hline Yillık ortalama değer & 84 & 73 & 55 & 56 & 55 \\
\hline Standart sapma & 64 & 68 & 56 & 43 & 38 \\
\hline
\end{tabular}

Yıllık ortalama değerlere ve günlük limit değerlerin aşıldığı gün sayılarına bakıldığında PM 10 kirliliğinin bu istasyon çevresinde yaşayan insanların sağlığı için ciddi bir risk oluşturduğu söylenebilir. Ölçülen yıllık ortalama değerler 2014 yılına kıyasla azalma eğilimi gösterse de 2017 ve 2018 yıllarında $\mathrm{PM}_{10}$ konsantrasyonlarında gözlenen ani artışlar günlük limitlerin çok üstünde kalarak daha riskli bir durum oluşturmaktadır. Son iki yılda gözlenen günlük aşım sayıları, Yönetmelik’te günlük limit değer için izin verilen aşım sayısının çok üstündedir.

Kocaeli Dilovası istasyonunda ölçülen hava kalitesi $\mathrm{SO}_{2}$ parametresi açısından incelendiğinde $\mathrm{SO}_{2}$ kirliğinin $\mathrm{PM}_{10}$ kirliliği kadar riskli bir durum oluşturmadığı söylenebilir. $\mathrm{SO}_{2}$ veri analizi sonuçları ve Yönetmelik'teki limit değerlerle kıyaslaması Tablo 11'de verilmiştir. Ölçülen $\mathrm{SO}_{2}$ konsantrasyonları Yönetmelik'te insan sağlığının korunması amacıyla belirlenen saatlik ve günlük limit değerlerle kıyaslandığında saatlik limit değerlerin 2015 yılında bir kez, 2016 yılında altı kez, 2017 yılında ise üç kez aşıldığı; günlük ortalama değerlerin beş yıl boyunca limit değerler altında kaldığı gözlenmiştir. Yönetmelik'te ekosistemlerin korunması amacıyla yıllık limit değer olarak $20 \mu \mathrm{g} / \mathrm{m}^{3}$ değeri belirlenmiş ve ölçülen konsantrasyonların yıllık ortalama değerleri bu değerle kıyaslanmıştır. Sadece 2017 yılında $21 \mu \mathrm{g} / \mathrm{m}^{3}$ değeri ile yıllık limit değer aşılmıştır.

Tablo 11. Kocaeli Dilovası İstasyonunda Ölçülen $\mathrm{SO}_{2}$ Konsantrasyonlarının Limit Değerlerle Kıyaslanması

\begin{tabular}{|c|c|c|c|c|c|}
\hline $\mathrm{SO}_{2}\left(\mu \mathrm{g} / \mathrm{m}^{3}\right)$ & 2014 & 2015 & 2016 & 2017 & 2018 \\
\hline Saatlik ölçüm sayısl-ölçüm yüzdesi & $7442-\% 85$ & $8125-\% 93$ & $8558-\% 97$ & $8519-\% 97$ & $8700-\% 99$ \\
\hline Saatlik en yüksek de ğer & 393 & 537 & 717 & 540 & 218 \\
\hline Saatlik limit değer* & 500 & 470 & 440 & 410 & 380 \\
\hline Saatlik limit değer için izin verilen aşım sayısı & 24 & 24 & 24 & 24 & 24 \\
\hline Saatlik aşım saylsı & 0 & 1 & 6 & 3 & 0 \\
\hline Uyarl eşiği & 500 & 500 & 500 & 500 & 500 \\
\hline Uyarı eşiği aşım sayısı & 0 & 1 & 3 & 1 & 0 \\
\hline Günlük ölçüm sayısl-ölçüm yüzdesi & $317-\% 87$ & $361-\% 99$ & $366-\% 100$ & $362-\% 99$ & $365-\% 100$ \\
\hline Günlük en yüksek değer & 77 & 84 & 121 & 137 & 50 \\
\hline Günlük limit değer* & 250 & 225 & 200 & 175 & 150 \\
\hline Günlük limit değer için izin verilen aşım sayısı ${ }^{*}$ & 3 & 3 & 3 & 3 & 3 \\
\hline Günlük aşım sayısı & 0 & 0 & 0 & 0 & 0 \\
\hline Ylllık limit değer** & 20 & 20 & 20 & 20 & 20 \\
\hline Yillık ortalama değer & 16 & 13 & 16 & 21 & 11 \\
\hline Standart sapma & 20 & 21 & 28 & 27 & 15 \\
\hline
\end{tabular}

Yönetmelik'e göre insan sağlığının korunması için $\mathrm{NO}_{2}$ parametresine, ekosistemin korunması için $\mathrm{NO}_{\mathrm{x}}$ parametresine dikkat edilmelidir. $\mathrm{NO}_{2}$ parametresi için saatlik ve yıllık limit değerler, $\mathrm{NO}_{\mathrm{x}}$ parametresi için sadece yıllık limit değer belirlenmiştir. Ölçülen $\mathrm{NO}_{2}$ kirlilik seviyeleri beş yıl boyunca yıllık limit değerlerinin altında kalmış ve en düşük kirlilik seviyesi 2018 yılında gözlenmiştir. Ancak Tablo 12 'de $\mathrm{NO}_{2}$ ve NO konsantrasyonlarının toplamı olarak hesaplanan yıllık ortalama $\mathrm{NO}_{\mathrm{x}}$ değerlerine bakıldığında her yıl limit değerlerin aşıldığı görülmektedir. 
Tablo 12. Kocaeli Dilovası İstasyonunda Ölçülen $N_{x}$ Konsantrasyonlarının Limit Değerlerle Kıyaslanması

\begin{tabular}{|c|c|c|c|c|c|}
\hline $\mathrm{NO}_{\mathrm{x}}\left(\mu \mathrm{g} / \mathrm{m}^{3}\right)$ & 2014 & 2015 & 2016 & 2017 & 2018 \\
\hline Saatlik ölçüm sayısı-ölçüm yüzdesi & $8522-\% 97$ & $8083-\% 92$ & $7993-\% 91$ & $8324-\% 95$ & $8437-\% 96$ \\
\hline Ylllık limit değer* & 30 & 30 & 30 & 30 & 30 \\
\hline Yıllık ortalama değer & 55 & 61 & 58 & 42 & 30 \\
\hline Standart sapma & 52 & 55 & 62 & 62 & 52 \\
\hline
\end{tabular}

Tablo 13'te Kocaeli Dilovası istasyonunda ölçülen CO kirliliğinin değerlendirmesi yapılmıştır. Yönetmelik'te CO kirletici parametresi için insan sağlığının korunması amacıyla günlük (maksimum 8 saatlik ortalama) limit değer belirlenmiştir. Saatlik olarak ölçülen CO konsantrasyonlarının günlük maksimum sekiz saatlik ortalamaları hesaplanmış ve bu değerlerin limit değerlerin çok altında olduğu görülmüştür. Dolayısıyla Kocaeli-Dilovası istasyonu çevresinde CO kirliliğinin insan sağlı̆̆ı açısından bir risk oluşturmadığı söylenebilir. Her yıl için hesaplanmış maksimum günlük 8 saatlik ortalama değerlerin Yönetmelik’te belirlenen alt değerlendirme eşiğinin dahi altında kaldığı gözlenmiștir. Dolayısıyla Yönetmelik'e göre; bu istasyon için CO kirliliğinin sürekli ölçümüne ihtiyaç duyulmadığı, sadece kaynak envanteri ve hava kalitesi modelleme sonuçlarının CO kirliliğinin izlenmesinde yeterli olacağı söylenebilir.

Tablo 13. Kocaeli Dilovası İstasyonunda Ölçülen CO Konsantrasyonlarının Limit Değerlerle Klyaslanması

\begin{tabular}{l|c|c|c|c|c}
\hline $\mathbf{C O}\left(\boldsymbol{\mu g} / \mathbf{m}^{\mathbf{3}}\right.$ ) & $\mathbf{2 0 1 4}$ & $\mathbf{2 0 1 5}$ & $\mathbf{2 0 1 6}$ & $\mathbf{2 0 1 7}$ & $\mathbf{2 0 1 8}$ \\
\hline Günlük (maksimum \& saatlik ortalama) ölçüm saylst-ölçüm yüzdesi & $316-\% 87$ & $345-\% 95$ & $357-\% 98$ & $361-\% 99$ & $360-\% 99$ \\
\hline Günlük (maksimum \& saatlik ortalama) en yüksek değer & 4306 & 4412 & 3142 & 3603 & 2747 \\
\hline Günlük (maksimum 8 saatlik ortalama) alt değerlendirme eşiği & 5000 & 5000 & 5000 & 5000 & 5000 \\
\hline Günlük (maksimum \& saatlik ortalama) limit değer* & 16000 & 14000 & 12000 & 10000 & 10000 \\
\hline Günlük (maksimum 8 saatlik ortalama) aşım sayılst & 0 & 0 & 0 & 0 & 0 \\
\hline
\end{tabular}

* İnsan sağlığının korunması için, yıllık tolerans paylarıyla birlikte hesaplanmış limit değerler.

Yönetmelik'te $\mathrm{O}_{3}$ parametresi için insan sağlı̆̆ının korunması amacıyla belirlenen limit değer 2022'de ulaşılması gereken hedef değerdir. Günlük maksimum sekiz saatlik ortalama hedef değer $120 \mu \mathrm{g} / \mathrm{m}^{3}$ ve bu değerin aşılması için izin verilen maksimum gün sayısı 25 'tir. $\mathrm{O}_{3}$ kirliliğinin beş yıllık değerlendirmesi Tablo 14 'te verilmiş ve değerlendirme sonucunda günlük limit değer için izin verilen aşım sayısının üstüne çıkılmadığı görülmüştür.

Tablo 14. Kocaeli Dilovası İstasyonunda Ölçülen $O_{3}$ Konsantrasyonlarının Limit Değerlerle Kıyaslanması

\begin{tabular}{|c|c|c|c|c|c|}
\hline$O_{3}\left(\mu \mathrm{g} / \mathrm{m}^{3}\right)$ & 2014 & 2015 & 2016 & 2017 & 2018 \\
\hline Saatlik ölçüm saylst-ölçüm yüzdesi & $6336-\% 72$ & $8065-\% 92$ & 7991-\%91 & $8289-\% 95$ & $7545-\% 86$ \\
\hline Saatlik en yüksek değer & 237 & 208 & 139 & 245 & 186 \\
\hline Ylllik ortalama değer & 39 & 43 & 36 & 37 & 44 \\
\hline Standart sapma & 28 & 29 & 24 & 30 & 30 \\
\hline $\begin{array}{l}\text { Günlük (maksimum } 8 \text { saatlik ortalama) ölçüm sayısl- } \\
\text { ölçüm yüzdesi }\end{array}$ & $278-\% 76$ & $351-\% 96$ & $345-\% 94$ & $361-\% 99$ & $313-\% 86$ \\
\hline Günlük (maksimum 8 saatlik ortalama) en yüksek değer & 149 & 140 & 101 & 163 & 144 \\
\hline Günlük (maksimum 8 saatlik ortalama) limit değer* & 120 & 120 & 120 & 120 & 120 \\
\hline $\begin{array}{l}\text { Günlük (maksimum } 8 \text { saatlik ortalama) limit değer için } \\
\text { izin verilen aşım sayısı }\end{array}$ & 25 & 25 & 25 & 25 & 25 \\
\hline Günlük (maksimum 8 saatlik ortalama) aşım saylsı & 1 & 4 & 0 & 14 & 5 \\
\hline
\end{tabular}

\subsection{Kocaeli Dilovası İMES OSB istasyonları}

Dlovası IMMES OSB alanı içinde MTHM'ne ait iki adet hava kalitesi istasyonu bulunmaktadır. Her iki istasyonda da $\mathrm{PM}_{10}, \mathrm{NO}$, $\mathrm{NO}_{2}, \mathrm{NO}_{\mathbf{x}}$ ve $\mathrm{CO}$ kirletici parametreleri ile meteorolojik parametrelerin saatlik ölçümleri yapılmaktadır. İki istasyonda da 2015 yılının son aylarında ölçüm yapılmaya başlandığından 01.01 .2016 ve 01.01 .2019 tarihleri arasındaki 3 yıllık ölçüm sonuçları değerlendirilmiştir. IMES OSB 1 istasyonu OSB arazisinin merkezine yakın bir konumda, IMES OSB 2 istasyonu ise OSB alanının kuzeydoğusunda, bölgenin sınırında bir noktada yer almaktadır.

Tablo 15'te İMES OSB 1 istasyonunda üç y1l boyunca ölçülen $\mathrm{PM}_{10}$ kirlilik seviyeleri verilmiştir. Yılllı ortalama değerlere göre en yüksek kirlilik seviyesi 2017 yılında gözlenmiştir. Y1llık limit değer sadece 2017 yıllında aşılmış olsa da üç yıl boyunca günlük limit değerin aşıldığı gün sayısı bir yıl için izin verilen aşım sayısının çok üstünde gözlenmiştir. Dolayısıyla üç yıldır bölgede çalışan insanların sağlı̆ıııın Yönetmelik’e göre tehdit altında olduğu söylenebilir. 
Tablo 15. Kocaeli Dilovası IMES OSB 1 İstasyonunda Ölçülen $P M_{10}$ Konsantrasyonlarının Limit Değerlerle Kıyaslanması

\begin{tabular}{|c|c|c|c|}
\hline$P M_{10}\left(\mu \mathrm{g} / \mathrm{m}^{3}\right)$ & 2016 & 2017 & 2018 \\
\hline Günlük ölçüm saylst-ölçüm yüzdesi & $351-\% 96$ & $338-\% 93$ & $341-\% 93$ \\
\hline Günlük en yüksek değer & 445 & 260 & 187 \\
\hline Günlük limit değer* & 80 & 70 & 60 \\
\hline Günlük limit değer için izin verilen aşım sayısı ${ }^{*}$ & 35 & 35 & 35 \\
\hline Günlük aşım sayısı & 42 & 92 & 73 \\
\hline Ylllık limit değer* & 52 & 48 & 44 \\
\hline Yullık ortalama değer & 50 & 56 & 39 \\
\hline Standart sapma & 47 & 49 & 38 \\
\hline
\end{tabular}

Tablo 16'da ise İMES OSB 2 istasyonunda ölçülen $\mathrm{PM}_{10}$ kirliliğinin değerlendirilmesi verilmiştir. Yılllık ortalama ve günlük limit değerin aşıldığı gün sayıları 2018 yılında $\mathrm{PM}_{10}$ kirliliğinin önceki yıllara kıyasla arttığını ancak limit değerler dâhilinde kalındığını göstermektedir. Dolayısıyla İMES OSB 2 istasyonu çevresinde gözlenen $\mathrm{PM}_{10}$ kirliliğinin insan sağllğı için tehlikeli boyutlarda olmadığı söylenebilir.

Tablo 16. Kocaeli Dilovası IMES OSB 2 İstasyonunda Ölçülen PM ${ }_{10}$ Konsantrasyonlarının Limit Değerlerle Klyaslanması

\begin{tabular}{|c|c|c|c|}
\hline $\mathrm{PM}_{10}\left(\mu \mathrm{g} / \mathrm{m}^{3}\right)$ & 2016 & 2017 & 2018 \\
\hline Günlük ölçüm saylsl-ölçüm yüzdesi & $353-\% 96$ & $360-\% 99$ & $356-\% 98$ \\
\hline Günlük en yüksek değer & 174 & 78 & 153 \\
\hline Günlük limit değer** & 80 & 70 & 60 \\
\hline Günlük limit değer için izin verilen aşım saylsı ${ }^{*}$ & 35 & 35 & 35 \\
\hline Günlük aşım sayılsı & 2 & 1 & 25 \\
\hline Ylllık limit değer* $^{*}$ & 52 & 48 & 44 \\
\hline Ylllık ortalama değer & 20 & 21 & 28 \\
\hline Standart sapma & 20 & 17 & 30 \\
\hline
\end{tabular}

$\mathrm{NO}_{2}$ kirlilik analizi sonuçlarına göre her iki istasyonda da yıllık ortalama $\mathrm{NO}_{2}$ konsantrasyonu yıllık limit değerin altında kalmıştır. Ayrıca tüm yıllar için ölçülen saatlik konsantrasyonlar insan sağlı̆̆ının korunması amacıyla belirlenen saatlik limitler dâhilindedir. Dolayısıyla bölgede gözlenen $\mathrm{NO}_{2}$ kirliliğinin insan sağlığı açısından ciddi bir tehlike oluşturmadığı yorumu yapılabilir.

Tablo 17'de İMES OSB 1 istasyonun da ölçülen $\mathrm{NO}_{\mathrm{x}}$ kirlilik değerlendirmesi verilmiştir. Bu taboda verilen yıllık ortalama $\mathrm{NO}_{\mathrm{x}}$ konsantrasyonları ekosistemin korunması için belirlenmiş olan yıllık limit değer ile kıyaslandığında üç yılda da limit değerin aşıldığı gözlenmiştir. 2017 yılında hem kirlilik ortalaması hem de standart sapma diğer yıllara kıyasla çok daha yüksek seviyelerde gözlenmiştir. $\mathrm{Bu}$ sapmalar $\mathrm{NO}$ parametresinden kaynaklanmaktadır. IMES OSB 2 istasyonunda ise $\mathrm{NO}_{\mathrm{x}}$ kirliliği ekosistem açısından bir tehdit oluşturmamaktadır.

Tablo 17. Kocaeli Dilovası IMES OSB 1 İstasyonunda Ölçülen NOx Konsantrasyonlarının Limit Değerlerle Kıyaslanması

\begin{tabular}{l|c|c|c}
\hline $\mathbf{N O}_{\mathbf{x}}\left(\boldsymbol{\mu g} / \mathbf{m}^{\mathbf{3}}\right)$ & $\mathbf{2 0 1 6}$ & $\mathbf{2 0 1 7}$ & $\mathbf{2 0 1 8}$ \\
\hline Saatlik ölçüm sayısı-ölçüm yüzdesi & $6988-\% 80$ & $6124-\% 70$ & $7045-\% 80$ \\
\hline Ylllkk limit değer* & 30 & 30 & 30 \\
\hline Ylllık ortalama dĕger & 41 & 69 & 40 \\
\hline Standart sapma & 53 & 92 & 46 \\
\hline * Ekosistemin korunması için, yılllk tolerans paylarılla birlikte hesaplanmış limit değerler.
\end{tabular}

Her iki istasyonda ölçülen CO konsantrasyonları Yönetmelik limit değerleriyle kıyaslandığında ise kirlilik seviyelerinin çok düşük olduğu, üç y1l boyunca gözlenen günlük en yüksek değerlerin limit değerler dahilinde ve alt değerlendirmeş eşiğinin altında olduğu görülmüştür.

\section{Sonuç}

Bu çalışmada Dilovası'nda yer alan dört adet hava kalitesi izleme istasyonunda son yıllarda ölçülen kirletici konsantrasyonları analiz edilmiş ve her bir istasyonda ölçülen kirlilik seviyeleri Hava Kalitesi Değerlendirme ve Yönetimi (HKDY) Yönetmeliği'ne göre değerlendirilmiştir. Yönetmelik'te insan sağllğının ve ekosistemin korunması amacıyla her bir kirletici parametre için saatlik, günlük ya da yıllık limit değerler belirlenmiş ve bu limit değerlerin aşılması halinde yapılması gereken faaliyetler açıklanmıştır. Ayrıca istasyonlarda hava kalitesinin sürekli sistemlerle izlenmesi gerekliliğini ortaya koyan alt ve üst eşik değerleri ile insan sağlı̆̆ için ciddi risk seviyesi anlamına gelen uyarı eşik seviyeleri tanımlanmıştır. 
D-100 ve E-80 karayollarına yakın bir konumda ve Dilovası Organize Sanayi Bölgesi'nin (DOSB) içinde yer alan Kocaeli OSB hava kalitesi izleme istasyonunda ölçülen kirlilik seviyelerine göre insan sağlığ 1 ve ekosistem için en fazla risk oluşturan kirleticiler $\mathrm{NO}_{\mathrm{x}}$ bileşikleridir. $\mathrm{NO}_{2}$ ve $\mathrm{NO}_{\mathrm{x}}$ konsantrasyonları beş yıl boyunca limit değerlerin çok üstünde gözlenmiştir. Özellikle 2017 yılından itibaren yıllık ortalama $\mathrm{NO}_{x}$ konsantrasyonları katlanarak artmış ve ekosistem üzerindeki tehditi artırmıştır. $\mathrm{SO}_{2}$ kirliliği zaman zaman uyarı eşiğini aşacak seviyelere ulaşmıştır ancak Yönetmelik'te insan sağlığının korunması için saatlik ve günlük limit değerler için izin verilen aşım sayılarının altında kalmıştır. $\mathrm{PM}_{10}$ kirlilik seviyeleri ise beş yıl boyunca insan sağlığının korunması amacıyla belirlenmiş limit değerler dahilinde gözlenniştir.

Kocaeli Dilovası istasyonu D-100 karayolu yakınında, yerleşim bölgesi içinde bir ilkokul bahçesinde yer almaktadır. Dolayısıyla doğrudan ilçede yaşayan insanların maruz kaldıkları hava kirliliğini ölçtüğü düşünülebilir. Bu istasyonda ölçülen parametreler arasında en tehlikeli kirletici $\mathrm{PM}_{10}$ 'dur. Beş yıl boyunca ölçülen kirlilik seviyeleri, günlük ve yıllık limit değerlerin çok üstünde gözlenmiş ve insan sağlığını tehdit edecek boyutlara ulaşmıştır. $\mathrm{SO}_{2}$ konsantrasyonları uyarı eşiğini ve limit değerleri zaman zaman aşmış olsa da insan sağlığı açısından oluşturduğu risk $\mathrm{PM}_{10}$ kirliliği kadar değildir. $\mathrm{NO}_{2}$ konsatrasyonları da limit değerler dahilinde gözlenmiş ancak yıllık ortalama $\mathrm{NO}_{\mathrm{x}}$ konsantrasyonları ekosistemin korunması amacıyla belirlenmiş limit değerleri beş yıl boyunca aşmıştır. $\mathrm{Bu}$ istasyonda $\mathrm{CO}$ ve $\mathrm{O}_{3}$ ölçümleri de yapılmaktadır. Ölçülen kirlilik seviyelerine göre bu kirleticilerin insan sağlı̆̆ açısından bir risk oluşturmadığı görülmüştür. Hatta, CO konsantrasyonları alt değerlendirme eşiğini aşmadığından Yönetmelik'e göre bu istasyon için CO kirliliğinin sürekli ölçümüne ihtiyaç duyulmadığı, sadece kaynak envanteri ve hava kalitesi modelleme sonuçlarının CO kirliliğinin izlenmesinde yeterli olacağı söylenebilir.

Dilovası İMES OSB alanı içinde bulunan iki istasyonda $\mathrm{PM}_{10}, \mathrm{NO}_{2}$ bileşikleri ve $\mathrm{CO}$ kirleticilerinin konsantrasyon ölçümleri yapılmaktadır. İMES OSB 1 istasyonu OSB arazisinin merkezine yakın bir konumda, tesislerin arasında; İMES OSB 2 istasyonu ise OSB alanının kuzeydoğusunda, bölgenin sınırında, orman arazisine yakın bir noktada yer almaktadır. İMES OSB 1 istasyonunda ölçülen $\mathrm{PM}_{10}$ kirlilik seviyeleri limit değerlerin çok üstünde olup insan sağlığını tehdit edecek boyutlara ulaşmışken, IMES OSB 2 istasyonunda ölçülen $\mathrm{PM}_{10}$ kirliliği limit değerlerin altında gözlenmiştir. $\mathrm{NO}_{2}$ kirliliği her iki istasyondaki ölçüm sonuçlarına göre bölgede insan sağlığı açısından bir risk oluşturmamakadır. Ancak IMES OSB 1 istasyonunda ölçülen yıllık ortalama $\mathrm{NO}_{\mathrm{x}}$ konsantrasyonları ekosistemin korunması amacıyla belirlenmiş yıllık limit değerlerin üstündedir. Her iki istasyonda da ölçülen CO kirlilik seviyeleri limit değerlerin ve alt değerlendirme eşiğinin altındadır.

Yönetmelik'e göre, limit değerlerin aşılması halinde il çevre ve orman müdüllükleri ilgili kurum ve kuruluşlarla koordinasyon içerisinde bir temiz hava planı hazırlamalıdır. Temiz hava planları, limit değerlere ulaşmak için alınması gereken önlemleri içermeli ve kamuoyuna sunulmalıdır. Uyarı eşiklerinin aşılması insan sağlığı için risk oluşturduğundan uyarı eşiklerinin aşılması durumunda da kamuoyunun bilgilendirilmesi gerekmektedir. Uyarı eşiklerinin aşılması durumunda aşımların süresini kısıtlamak ve aşım risklerini azaltmak için kısa vadede alınacak önlemleri içeren bir eylem planı hazırlanmalıdır. Eylem planları, hava kirliliğini artıran motorlu araç trafiğini de içeren faaliyetleri kontrol etmek ve gerektiğinde askıya almak için gerekli önlemleri içerebilir ve temiz hava planlarının bir parçası olabilir. Örneğin; D-100 ve E-80 karayollarına yakınlıkları sebebiyle, Kocaeli OSB istasyonunda $\mathrm{NO}_{\mathrm{x}}$ kirleticilerinin ve Kocaeli Dilovası istayonunda $\mathrm{PM}_{10}$ kirleticisinin yüksek seviyelerde gözlendiği düşünülebilir ve kirlilik seviyelerini düşürmek amacıyla bu yollardaki araç trafiğini azaltacak alternatif yöntemler temiz hava planlarında önerilebilir.

\section{Teşekkür}

Katkılarından dolayı TÜBİTAK'a (Proje No:117Y298) ve hava kalitesi verilerini kullanımımıza açan T.C Çevre ve Şehircilik Bakanlı̆̆ı'na teşekkür ederiz.

\section{Kaynakça}

Andre, L., Boissière, J., Reboul, C., Perrier, R., Zalvidea, S., Meyer, G., Thireau, J., Tanguy, S., Bideaux, P., Hayot, M., Boucher, F., Obert, P., Cazorla, O. ve Richard, S. (2009). Carbon Monoxide Pollution Promotes Cardiac Remodeling and Ventricular Arrhythmia in Healthy Rats. American Journal of Respiratory and Critical Care Medicine, 181 (6), 587-595.

Brunekreef, B. ve Holgate, S. T. (2002). Air Pollution and Health. The Lancet, 360(9341), 1233-1242.

CEC (Commission of the European Communities), 2008: Directive 2008/50/EC of the European Parliament and of the Council of 21 May 2008 on ambient air quality and cleaner air for Europe. Official Journal of the European Union, L152, 1-44.

Chen, T.-M., Kuschner, W.G., Gokhale, J. ve Shofer, S. (2007). Outdoor Air Pollution: Nitrogen Dioxide, Sulfur Dioxide, and Carbon Monoxide Health Effects. The American Journal of the Medical Sciences, 333(4), 249-256.

Çapraz, Ö., Deniz, A. ve Doğan, N. (2017). Effects of air pollution on respiratory hospital admissions in Istanbul, Turkey, 2013 to 2015. Chemosphere, 181, 544-550.

ÇŞB, (2019a). T.C. Çevre ve Şehircilik Bakanlığı, Marmara Temiz Hava Merkezi, Hava Kalitesi İndeksi, http://mthm.havaizleme.gov.tr/secure/HAVA\%20KAL\%DDTES\%DD\%20\%DDNDEKS\%DD.htm (Erişim tarihi: 11.09.2019)

ÇŞB, (2019b). T.C. Çevre ve Şehircilik Bakanlığı, Ulusal Hava Kalitesi İzleme Ağı, https://www.havaizleme.gov.tr/ (Erişim tarihi: 11.09.2019)

Dilovası Belediyesi (2019). Dilovası'nı Tanıyalım, http://dilovasi.bel.tr/icerik/17/13/dilovasini-taniyalim.aspx (Erişim tarihi: 11.09.2019)

DOSB (2019). Kocaeli Dilovası Organize Sanayi Bölgesi, Tarihçe, http://dosb.com.tr/TR/Contents.aspx?ID=3 (Erişim tarihi: 11.09.2019) 
Ebi K.L. ve McGregor G., 2008. Climate Change, Tropospheric Ozone and Particulate Matter, and Health Impacts. Environ. Health Perspectives, 116(11): 1449-1455.

EPA (U.S. Environmental Protection Agency), 2012. Report to Congress on Black Carbon, 388.

Feng, L. ve Liao, W. (2016). Legislation, plans, and policies for prevention and control of air pollution in China: achievements, challenges, and improvements. Journal of Cleaner Production, 112, 1549-1558.

Freeman, B.S., Taylor, G., Gharabaghi, B. ve The, J. (2018). Forecasting air quality time series using deep learning. Journal of the Air \& Waste Management Association, 68(8), 866-886.

Gemici Z., Kale O., Yuva H. ve Çaçan İ. (2017). Hava Kalitesi İzleme Sürecinde Yasal Yükümlülükler, VII. Ulusal Hava Kirliliği ve Kontrolü Sempozyumu, 1-3 Kasım, Antalya.

Gemmer, M. ve Bo, X. (2013). Air Quality Legislation and Standards in the European Union: Background, Status and Public Participation. Advances in Climate Change Research, 4(1), 50-59.

Güler, Ç., 1993. Hava Kirliliği, Hatipoğlu Yayınevi, Ankara.

HKDYY (2008). Hava Kalitesi Değerlendirme ve Yönetimi Yönetmeliği, T.C. Resmi Gazete (26898, 06.06.2008)

Iwamoto, M. ve Hamada, H. (1991). Removal of nitrogen monoxide from exhaust gases through novel catalytic processes. Catalysis Today, 10(1), 57-71.

İMES OSB (2019). VI. Makine İhtisas Organize Sanayi Bölgesi, Hakkımızda, https://imesdilovasi.org/hakkimizda/ (Erişim tarihi: 11.09.2019)

Li, H., Wang, J., Li, R. ve Lu, H. (2019). Novel analysis-forecast system based on multi-objective optimization for air quality index. Journal of Cleaner Production, 208, 1365-1383.

MARKA (2012). Green Kocaeli-Gelişmiş Rehabilite ve Endüstriyel Nüanslarla Kocaeli'de Çevre Konsepti Çalıştay Kitabı, Kocaeli Çevre ve Şehircilik İl Müdürlüğü, Doğu Marmara Kalkınma Ajansı (MARKA) Doğrudan Faaliyet Destek Programı.

Mazzei F., D'Alessandro A., Lucarelli F., Nava S., Prati P., Valli G. ve Vecchi R. (2008). Characterization of particulate matter sources in an urban environment, Science of The Total Environment, 401 (1-3), 81-89.

Özdemir, E.T. (2019). Investigations of a Southerly Non-Convective High Wind Event in Turkey and Effects on PM10 Values: A Case Study on April 18, 2012. Pure and Applied Geophysics, 176, 4599-4622.

Özdemir, E.T., Deniz, A., Yavuz, V., Doğan, N. ve Akbayır, İ. (2018). Investigation of Fog-Air Quality Relationship in Istanbul, Fresenius Environmental Bulletin, 27(1), 30-36.

Öztürk Z., Arslantaş O.A., Emanet Beba H., Yılmaz M., Toros H., (2019). Air Pollution Reduction with Intelligent Transportation Systems: Dilovası Scenario, Journal of Research in Atmospheric Science, 1(1), 12-17.

Raub, J.A, Mathieu-Nolf, M., Hampson, N.B. ve Thom, S.R. (2000). Carbon Monoxide Poisoning - A Public Health Perspective. Toxicology, 145(1), 1-14.

Tam, C.W., Bevan, R.J., Harrison, P.T.C., Youngs, L.C. ve Crump, D. (2012). Public Health Impacts of Exposure to Carbon Monoxide From Gas Appliances in UK Homes - Are We Missing Something? Indoor and Built Environment, 21(2), $229-240$.

Toros H., 2000. İstanbul'da Asit Yağışları, Kaynakları ve Etkileri, Doktora Tezi, 110s, İTÜ

TÜİK (2019). Adrese Dayalı Nüfus Kayıt İstatistikleri, İl ve İlçelere Göre İl/İlçe Merkezi, Belde/Köy Nüfusu ve Yıllık Nüfus Artış Hızı, http://www.tuik.gov.tr/PreIstatistikTablo.do?istab id=2305 (Erişim Tarihi: 11.06.2020)

Unal, Y.S., Toros, H., Deniz, A. ve Incecik, S. (2011). Influence of meteorological factors and emission sources on spatial and temporal variations of PM10 concentrations in Istanbul metropolitan area. Atmospheric Environment, 45, 5504-5513.

Vallero, D. A. (2014). Fundamentals of Air Pollution (5th ed.). Academic Press.

Yılmaz M., Toros H., İncecik S., Öztürk Z., Kirkil G., Öztaş D., Akçay M., Dinç U., Gültekin M., Emanet H., Arslantaş O.A. (2019). Investigation of Air Pollution Using a Model in Dilovas1 and Gebze Region: A New Approach, Journal of Research in Atmospheric Science, 1(1), 49-52.

WHO, (2003). Health Aspects of Air Pollution with Particulate Matter, Ozone and Nitrogen Dioxide, http://www.euro.who.int/_data/assets/pdf_file/0005/112199/E79097.pdf

Wigenstam, E., Elfsmark, L., Bucht, A. ve Jonasson, S. (2016). Inhaled sulfur dioxide causes pulmonary and systemic inflammation leading to fibrotic respiratory disease in a rat model of chemical-induced lung injury. Toxicology, 368, 28-36.

Zheng, Y., Yi, X., Li, M., Li., R., Shan, Z., Chang, E. ve Li, T. (2015). Forecasting Fine-Grained Air Quality Based on Big Data, 21th ACM SIGKDD Conference on Knowledge Discovery and Data Mining, 10-13 August 2015, Sydney. 